DOI: https://doi.org/10.32839/2304-5809/2020-12-88-62

УДК 811.111.161.2'25

Райська Л.В., Глінка Н.В.

Національний технічний університет України

«Київський політехнічний інститут імені Ігоря Сікорського»

\title{
РОЛЬ ПЕРЕКЛАДАЦЬКИХ ТРАНСФОРМАЦІЙ У ДОСЯГНЕННІ АДЕКВАТНОСТІ ТА ЕКВІВАЛЕНТНОСТІ ПЕРЕКЛАДУ ТЕКСТУ У ГАЛУЗІ МЕДИЦИНИ
}

\begin{abstract}
Анотація. Стаття присвячена дослідженню такого важливого для перекладознавчої науки явища, як перекладацькі трансрормації, які являють собою певні міжмовні перетворення, покликані зберегти та передати зміст та функцію повідомлення тексту оригіналу у тексті перекладу. В цьому дослідженні розглядаються ті трансформаційні перетворення, які використовуються при перекладі англомовного науково-популярного тексту (Олівер Сакс: «Чоловік, який сплутав дружину з капелюхом та інші історії 3 лікарської практики») на медичну тематику. У статті наведені реальні приклади використання перекладацьких трансформацій у медичному тексті, відібрані з матеріалу доследження. Крім того, визначені найчастотніші трансформаційні перетворення, характерні для досліджуваного матеріалу, а саме: транскрибування, транслітерація, адаптивне транскодування, калькування, експлікація, субституція та інші. В роботі обгрунтована необхідність використання таких трансформацій при перекладі задля досягнення адекватності та еквівалентності тексту перекладу.
\end{abstract}

Ключові слова: переклад, перекладацькі трансформації, адекватність, еквівалентність, медичний текст.

Raiska Liena, Hlinka Nataliia National Technical University of Ukraine "Igor Sikorsky Kyiv Polytechnic Institute"

\section{THE ROLE OF TRANSLATION TRANSFORMATIONS TO ACHIEVE THE ADEQUACY AND EQUIVALENCE OF THE TEXT IN THE FIELD OF MEDICINE}

Summary. The article is devoted to the study of such an important translation phenomenon as translation transformations, which are certain interlingual transformations which are used to preserve and convey the content and function of the message of the original text in the translated text. A large number of researchers have studied the phenomenon of translation transformations and tried to define and classify them. However, the study of the use of translation transformations in the medical text is an area that has so far been insufficiently studied. The translation of medical text is one of the most important issues in translation studies, as the results of the translation of medical texts can directly affect people's lives and health. Although the medical literature is usually associated mainly with technical text, which has its own strict rules of translation, there are many variants of medical texts of different substyles and genres, as well as ways to translate them. This particular study examined the transformations used in the translation of English popular science text (Oliver Sacks: "The man who mistook his wife for a hat and other clinical tales") on medical topic. The article presents real examples of the use of translation transformations in the such a medical text, selected from the research material. The transformations which were used most often are also specified in this article, such as: transcription, transliteration, adaptive transcoding, explication, substitution, transformation based on antonymy and others. The article investigates and substantiates the need to use such transformations to achieve equivalence and adequacy of the translated text as well as draws a line between these two concepts. In addition, this paper defines the level of equivalence of the translated text (research material) according to the levels of equivalence of Komissarov V.N. The translated text we are studying is at the fourth level of equivalence, because it meets all the characteristics inherent in this level. This article is an attempt to identify opportunities for the use of translation transformations in medical texts, namely in popular science texts, as well as to identify the main transformations used in such texts and their role to achieve the adequacy and equivalence of translation.

Keywords: translation, translation transformations, adequacy, equivalence, medical text.

$\Pi$ остановка проблеми. Переклад медичного тексту та медичної лексики відноситься до одного 3 найважливіших питань перекладознавства, адже результати перекладу медичних текстів можуть безпосередньо впливати на життя та здоров'я людей. Медична лексика найчастіше реалізовується у текстах науковотехнічного фрункціонального стилю і у такому випадку переклад відбувається за канонами науково-технічного перекладу і має бути максимально наближеним до оригінала. Неточності і двозначність виключені. Однак, медична лексика, оточуючи нас повсюди і щоденно - на вулиці, по телевізору, в книжках тощо, може реалізовуватись у текстах різних фрункціональних стилів, підстилів та жанрів.
В цій статті текст, що використовуе велику кількість медичної лексики, розглядається на матеріалі книги, яку можна віднести до науково-популярного стилю, «Чоловік, який сплутав дружину 3 капелюхом та інші історії 3 лікарської практики» Олівера Вулфа Сакса у зіставленні 3 перекладом цієї книги у виконанні Олени Опанасенко, виданим в Україні в 2017 році. Будучи одночасно насиченим великою кількістю термінологічної та нетермінологічної медичної лексики і різноманітними художніми засобами, цей твір 3 його перекладом має великий потенціал для дослідження різноманітних способів перекладу творів медичного спрямування поза межами науково-технічного тексту. 
Отже, в центрі уваги ціеї статті знаходяться перекладацькі трансформації, які зазначений вище перекладач використовував при перекладі насиченого медичною лексикою тексту для досягнення адекватності та еквівалентності тексту перекладу.

Аналіз останніх досліджень та публікацій. Питання перекладацьких трансформаційних перетворень досліджувала велика кількість науковців. I, хоча, одностайності в питанні визначення цього поняття та класифікації таких трансформацій не існуе досі, перекладацькі трансформації, е основою більшості перекладів та широко використовуються при дослідженнях перекладу.

Особливу увагу дослідженню перекладацьких трансформацій приділяли такі науковці як: О.О. Селіванова, на думку якої, суть трансформацій полягає в зміні формальних або семантичних одиниць вихідного тексту при збереженні інформації, яку необхідно передати [8, с. 201]; Я.Й. Рецкер, який вважає, що трансформації-це певні прийоми логічного мислення, за допомогою яких розкривається значення іншомовного слова в контексті і знаходиться відповідник цього слова, який не зовсім збігається зі словниковим відповідником [7, с. 82]; В.Г. Гак, який визначае трансформації, як міжмовні перетворення, які застосовуються з метою досягнення еквівалентності текстів оригіналу й перекладу і необхідні для збереження функціонального впливу повідомлення тексту оригіналу [3, с. 55].

Крім того, важливий внесок у дослідження з цієї теми зробили Л.С. Бархударов, О.Д. Швейцер, Р.К. Міньяр-Білоручев та А.М. Фітерман спільно з Т.Р. Левицькою.

Так, наприклад, А.М. Фітерман та Т.Р. Левищька у спільній праці розрізняють такі три види перекладацьких трансформацій як: граматичні трансформації, до яких відносять різноманітні перестановки, опущення і додавання, перебудови та заміни; стилістичні трансформації, до яких відносять такі прийоми, як синонімічні заміни та описовий переклад, а також компенсацію; лексичні трансформації, до яких відносять заміну і додавання, конкретизацію і генералізацію [5, с. 172].

О.Д. Швейцер, в свою чергу, вирізняе такі типи перекладацьких трансформацій як: трансформації на компонентному рівні семантичної валентності тобто заміна певних морфологічних засобів лексичними, іншими морфологічними, синтаксичними або фразеологічними засобами тощо; трансформації на рефреренціальному рівні, куди відносять конкретизацію, генералізаці, заміну реалій, метонімічні трансформації, реметафорізацію, деметафоризацію, а також різноманітні поеднання зазначених трансформацій; трансформації на стилістичному рівні - компресія та розширення [9, с. 157].

Р.К. Міньяр-Білоручев також виділяе три види трансформацій: лексичні трансформації: прийоми генералізації і конкретизації; граматичні трансформації: прийоми пасивізації, заміна частин мови і членів речення, об’еднання речень або їх членування; семантичні трансформації: синонімічні, метафоричні заміни, логічний розвиток понять, антонімічний переклад і прийом компенсації [6, с. 25].
Свій погляд на питання перекладацьких трансформацій також висловив В.Н. Комісаров. Иого класифікація $є$ досить повною та детальною. Лінгвіст розрізняе такі групи трансформащій: транскрипщія, транслітеращія; калькування; лексико-семантичні заміни, до яких відносимо конкретизащію, генералізацію, модулящію; граматичну трансформацію; комплексні лексико-граматичні трансформації, до яких відносимо антонімічний переклад, експлікацію, компенсацію [4, с. 32].

Виділення невирішених раніше частин загальної проблеми. Зазвичай, найбільша увага приділяеться трансформаціям у художньому тексті, адже, переклад такого тексту дає найбільше можливостей для всебічної реалізації різноманітних трансформаційних прийомів. Переклад текстів наукового стилю, хоча і не такий різноманітний в цьому плані, проте теж вартий уваги.

Особливо медичні тексти певних менш поширених у цій галузі наукового знання підстилів та жанрів, таких як, наприклад, науково-популярний стиль, можуть використовувати велику кількість різноманітних трансформаційних прийомів, які допомагають досягнути адекватної та еквівалентної передачі синтаксичних, лексичних та граматичних одиниць тексту оригіналу синтаксичними, лексичними та граматичними засобами рідної мови.

У цій статті розглядаються можливості використання таких прийомів на матеріалі реально виконаного українського перекладу збірки «Чоловік, який сплутав дружину з капелюхом та інші історії з лікарської практики» Олівера Сакса, яку за стилем визначають, як науково-популярну, а за жанром, як анамнез та/або есе.

Цілями дослідження є: визначення поняття перекладацьких трансформацій; визначення понятть еквівалентність та адекватність; визначення відмінності між поняттями адекватності та еквівалентності; встановлення найчастотніших трансформацій у медичному науково-популярному тексті; обгрунтування необхідності використання перекладацьких трансформацій для досягнення адекватності та еквівалентності тексту перекладу; визначення рівня еквівалентності досліджуваного тексту перекладу.

Матеріалом дослідження слугували: книга "The Man Who Mistook His Wife for a Hat and Other Clinical Tales" Олівера Вулфа Сакса (1985) та іiі український переклад у виконанні Олени Опанасенко (2017).

Виклад основного матеріалу дослідження. Порівнявши текст оригіналу з текстом українського перекладу ми дійшли висновків, що на рівні речення перекладу даного тексту характерні різноманітні об'єднання, членування та перестановки. Наведемо приклад $[1 ; 2]$ :

\begin{tabular}{|l|l|}
\hline If a man has lost a leg or & Коли людина втрачає \\
an eye, he knows he has & ногу або око, то знає про \\
lost a leg or an eye; but if & цю втрату. Коли жона вона \\
he has lost a self-himself- & втрачає себе, своє власне \\
he cannot know it, because & "я», то не ложе иього \\
he is no longer there to & знати, адже знати вже \\
know it. & немає колу. \\
\hline
\end{tabular}

$\mathrm{y}$ цьому ж уривку бачимо приклад такої граматичної трансформації, як субституція або заміна, в даному випадку субституція часової форми (has lost-втрачаe), а також субституція частини 
мови (has lost - втрату). Субституція частини мови, в свою чергу, дозволяе вилучити «зайві» повторювані елементи - a leg or an eye.

Окрім прямих еквівалентів (physician - лiкар, diseases - хвороби, vertigo - запалорочення, prosthesis - npoтез), перекладач часто використовував варіантні відповідники (cases - дослідження, disorders - порушення, capacity - здатність), а також, так звані, оказіональні відповідники або контекстуальні заміни (routine - процедура, to see - обстежити, session - огляд).

У багатьох випадках медичні терміни перекладалися за допомогою того чи іншого виду транскодуванння, а саме: транскрибування (aphonia - аббонія, aphemia - agбелія, aphasia аøбазія, alexia - алексія), транслітерація (mnemonist - лнелоніст, organism - організл, meningioma - менінгіола), а також адаптивне транскодування (rehabilitation - реабілітаuія, atrophy - ampogbiя, exteroception - екстероцепцiя).

Зазначені трансформації $є$ найчастотнішими, якщо розглядати окремі лексичні термінологічні та нетермінологічні одиниці тексту. Якщо ж розглядати словосполучення чи контекстуально зумовлені уривки речень, можна дослідити реалізацію значно більшої кількості різноманітних трансформацій, таких як, наприклад: калькування (neurology of identity - неврологія ідентичності, loss of speech - втрата мовлення); вилучення (proprioceptive body-model - nponріоиептивну модель, impersonal neurological science - безособовій неврологіï), додавання (acute polyneuritis гостру борлу поліневриту, gnostic systems - систела гностичної чутливості), експлікація (auditory feedback - слухового сприйняття та орієнтування на звуки), модуляція (seizures - епілептичні напади).

Значно менш часто при перекладі твору, який є матеріалом нашого дослідження, проте такими, на які необхідно звернути увагу виявилися наступні трансорормації: антонімічний переклад (it is easy to demonstrate the effects of variously located lesions on the left side - наслідки різноланітних пошкоджень лівої півкулі зафбіксувати не так складно), цілісне перетворення (The Working Brain - Основи нейропсихологіï), метафоризація (amytal injection ін'єкиілми "сироватки правди»).

Крім того, перекладач часто використовував такі трансорормації як: вже зазначена субституція (clinical curios - клінічні курйози (заміна числа)) та пермутація ('centers' in the brain - мозковили "иентрали»).

Загалом, дослідивши використання різноманітних трансорормацій при перекладі зазначеного творуговоримо про певний рівень еквівалентності текстів оригіналу та перекладу та досягнення адекватності тексту перекладу.

При чому, під адекватним перекладом розуміємо якісний переклад, тобто такий, який забезпечуе необхідну повноту міжмовної комунікації в конкретних умовах. Водночас, під терміном «еквівалентність» розуміємо смислову спільність прирівнюваних одна до одної одиниць мови i мовлення, відповідно до думки висловленої В.Н. Комісаровим [4, с. 53].

В.Н. Комісаров у своїх роботах, присвячених дослідженню еквівалентності перекладу, визначив п’ять змістовних рівнів, які відповідають певному ступеню збереження ознак оригіналу в тексті перекладу, а отже еквівалентності перекладу. Серед таких рівнів: рівень мети комунікації; рівень опису ситуації; рівень висловлювання; рівень повідомлення; рівень мовних знаків [4, с. 55-59].

Порівнявши текст оригіналу оригіналу досліджуваного матеріалу 3 текстом україномовного перекладу твору й визначивши перекладацькі трансформації, які використовував перекладач говоримо про певний рівень еквівалентності перекладу. А саме - у тексті перекладу збережена мета комунікації тексту оригіналу, збережена вказівка на описувану в оригіналі ситуацію, збереження загальних понять, за допомогою яких опис ситуащї відбувається в оригінальному тексті, а також неповний але значний лексичний та синтаксичний паралелізм. Всі названі риси притаманні четвертому рівню еквівалентності - рівню повідомлення.

Для того, щоб обгрунтувати необхідність використання трансформащйних перетворень, наведемо ще один уривок з тексту одного з розділів «Чоловік, який сплутав дружину з капелюхом» [1; 2].

\begin{tabular}{|c|c|}
\hline $\begin{array}{l}\text { Its radical flux and } \\
\text { incoherence could not be } \\
\text { tolerated, acknowledged, } \\
\text { for an instant-there } \\
\text { was, instead, this } \\
\text { strange, delirious, } \\
\text { quasi-coherence, as Mr } \\
\text { Thompson, with his } \\
\text { ceaseless, unconscious, } \\
\text { quick-fire inventions, } \\
\text { continually improvised a } \\
\text { world around him-an } \\
\text { Arabian Nights world, } \\
\text { a phantasmagoria, } \\
\text { a dream, of ever- } \\
\text { changing people, figures, } \\
\text { situations-continual, } \\
\text { kaleidoscopic mutations } \\
\text { and transformations. }\end{array}$ & 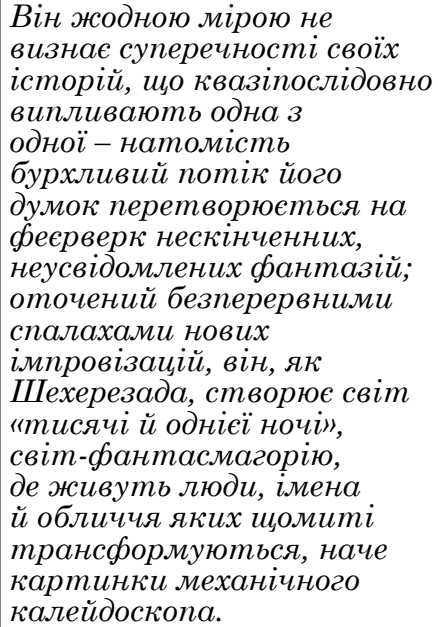 \\
\hline
\end{tabular}

Бачимо, що при досить точній передачі сенсу оригіналу у мові перекладу, текст при перекладі все ж зазнав значних змін. До того ж, наведений уривок чудово демонструє наявність у тексті перекладу такої перекладацької трансформації, як пермутації, тобто перестановки.

Також необхідно виділити використання досить цікавої метафори, яку використовуе автор: improvised a world around him - an Arabian Nights world, і яка в перекладі перетворилася на метафору і порівняння одночасно: він, як Шехерезада, створюе світ "тисячі й однієї ночі».

Олена Опанасенко, яка перекладала даний твір зробила досить об ємну й складну роботу як перекладач. Зробивши велику кількість змін, вона тим не менш, вона зуміла зберегти та передати в повній мірі зміст тексту, висловивши його зрозумілими для реципіента перекладу словами.

Перекладач розширює текст, виймає на поверхню імпліцитну інформацію, робить багато перестановок, вилучень та додавань, які, в свою чергу призводять до субституції. Наприклад: kaleidoscopic mutations and transformations - трансбборлуютьсл, наче картинки механічного калейдоскопа. Інформащія, вилучена в одному місці оригінального тексту, в перекладі компенсуеться в іншому місці.

Висновки і пропозиції. Узагальнюючи викладене, говоримо про неможливість адекватно- 
го перекладу без використання трансформаційних перетворень. Можна стверджувати, що без описаних у статті перетворень переклад був би не зрозумілим реципіенту тексту і не міг би досягнути такого ж комунікативного впливу, що оригінал, а отже не був би адекватним i, відповідно, еквівалентним. Саме цим обгрунтовуеться необхідність використання трансорормаційних перетворень при перекладі.
Отже, використання трансформацій різних типів при перекладі науково-популярного медичного тексту не тільки можливе, але й необхідне для досягнення еквівалентності та адекватності перекладу. Звідси випливає, що перекладач має не тільки бездоганно володіти мовою оригіналу та мовою перекладу та знаннями з галузі, у якій він перекладає, але й добре розумітися на трансформаційних перетвореннях.

\section{Список літератури:}

1. Oliver W. Sacks: The man who mistook his wife for a hat and other clinical tales. New York : Simon \& Schuster, 1987. $233 \mathrm{p}$.

2. Олівер Сакс, пер. Олена Опанасенко. Чоловік, який сплутав дружину з капелюхом та інші історії з лікарської практики. Київ : Наш формат, 2017. 288 с.

3. Гак В.Г. Языковые преобразования : моноградия. Москва : Языки русской культуры, 1998. 768 с.

4. Комиссаров В.Н. "Теория перевода (лингвистические аспекты)" : Учебник для ин-тов и фрак. иностр. яз. Москва : Высшая школа, 1990. 252 с.

5. Левицкая Т.Р., Фиттерман А.М. Проблемы перевода. Москва : Международные отношения, 1976. 264 с.

6. Миньяр-Белоручев Р.К. Общая теория перевода и устный перевод. Москва : Воениздат, 1980. 237 с.

7. Рецкер Я.И. Теория перевода и переводческая практика. Москва : Международные отношения, 1974.214 с.

8. Селіванова О.О. Лінгвістична енциклопедія. Полтава : Довкілля, 2011. 844 с.

9. Швейцер А.Д. Перевод и лингвистика: Статус, проблемы, аспекты. Москва : Наука, 1988. 215 с.

\section{References:}

1. Oliver W. Sacks (1987) The man who mistook his wife for a hat and other clinical tales. New York: Simon \& Schuster, p. 233

2. Oliver Sacks, per. Olena Opanasenko (2017) Cholovik, yakyj splutav druzhynu z kapelyuhom ta inshi istoriyi z likarskoyi praktyky [The man who mistook his wife for a hat and other clinical tales]. Kyiv: Nash Format, 288 p. (in Ukrainian)

3. Gak V.G. (1998) Yazykovye preobrazovanya: monografya [Language transformations: monograph]. Moscow: Yazyki russkoj kul'tury, p. 55. (in Russian)

4. Komysarov V.N. (1990) "Teorya perevoda (lyngvystycheskye aspekty)": Uchebnyk dlya in-tov in-tov fak. ynostr. yaz. ["Translation theory (linguistic aspects)". Textbook for institutes and fac. of foreign lang.]. Moscow: Vyshchaya shkola, p. 25. (in Russian)

5. Levyczkaya T.R., Fytterman A.M. (1976) Problemy perevoda [Translation problems]. Moscow: Mezhdunarodnye otnosheniya, p. 172. (in Russian)

6. Mynyar-Beloruchev R.K. (1980) Obshhaya teorya perevoda yustniy perevoda [General theory of translation and interpretation]. Moscow: Voenizdat, 237 p. (in Russian)

7. Reczker Ya.Y. (1974) Teorya perevoda, perevodcheskaya praktyka [Translation theory and translation practice]. Moscow: Mezhdunarodnye otnosheniya, p. 82. (in Russian)

8. Selivanova O.O. (2011) Lingvistychna encyklopediya [Linguistic encyclopedia]. Poltava: Dovkillya, p. 201. (in Ukrainian)

9. Shvejcer A.D. (1988) Perevod, lyngvystyka: Status, problemy, aspekty [Translation and linguistics: status, problems, aspects]. Moscow: Nauka, p. 157. (in Russian) 